\title{
Cilia and Mucociliary Clearance
}

\author{
Ximena M. Bustamante-Marin and Lawrence E. Ostrowski \\ Marsico Lung Institute, Cystic Fibrosis and Pulmonary Diseases Research and Treatment Center, University \\ of North Carolina, Chapel Hill, North Carolina 27599 \\ Correspondence: ostro@med.unc.edu
}

\begin{abstract}
Mucociliary clearance (MCC) is the primary innate defense mechanism of the lung. The functional components are the protective mucous layer, the airway surface liquid layer, and the cilia on the surface of ciliated cells. The cilia are specialized organelles that beat in metachronal waves to propel pathogens and inhaled particles trapped in the mucous layer out of the airways. In health this clearance mechanism is effective, but in patients with primary cilia dyskinesia (PCD) the cilia are abnormal, resulting in deficient MCC and chronic lung disease. This demonstrates the critical importance of the cilia for human health. In this review, we summarize the current knowledge of the components of the MCC apparatus, focusing on the role of cilia in MCC.
\end{abstract}

$T_{\text {the }}^{\mathrm{h}}$ he extensive epithelial surface of the respiratory tract between the nose and the alveoli is exposed daily to viral and bacterial pathogens, particulates, and gaseous material with potentially harmful effects. In response to these challenges, humans have developed a series of defense mechanisms to protect the airways from these insults, thereby maintaining the lungs in a nearly sterile condition (Dickson and Huffnagle 2015). Lung defense involves cough, anatomical barriers, aerodynamic changes, and immune mechanisms; however, the primary defense mechanism is mucociliary clearance (MCC). Healthy airway surfaces are lined by ciliated epithelial cells and covered with an airway surface layer (ASL), which has two components, a mucus layer that entraps inhaled particles and foreign pathogens, and a low viscosity periciliary layer (PCL) that lubricates airway surfaces and facilitates ciliary beating for efficient mucus clearance (Wanner et al. 1996; Knowles and Boucher 2002). The coordinated interaction of these components on the surface of the respiratory tract results in MCC.

Proper ciliary function is absolutely required for effective MCC. Cilia are specialized organelles that provide the force necessary to transport foreign materials in the respiratory tract toward the mouth where they can be swallowed or expectorated. To accomplish this crucial function, the cilia beat in coordinated metachronal waves at a beat frequency that has multiple physiological regulators. Much of what we know about cilia structure and function has been derived from studies performed using Chlamydomonas as a model, while the importance of cilia in maintaining airway clearance was revealed by clinical and pathological studies of genetic and acquired forms of chronic airway diseases, including primary ciliary dyskinesia

Editors: Wallace Marshall and Renata Basto

Additional Perspectives on Cilia available at www.cshperspectives.org

Copyright (C) 2017 Cold Spring Harbor Laboratory Press; all rights reserved; doi: 10.1101/cshperspect.a028241

Cite this article as Cold Spring Harb Perspect Biol 2017;9:a028241 
(PCD), cystic fibrosis (CF), asthma, and chronic obstructive pulmonary disease (COPD). In this review, we summarize the current knowledge of the components of MCC, with an emphasis on the role of cilia in normal mucociliary transport. We then briefly describe the health effects of impaired MCC caused by genetic defects in cilia in patients with PCD.

\section{ORIGIN AND ORGANIZATION OF THE RESPIRATORY TRACT}

In humans, the formation of the respiratory system starts around the fourth week of gestation. In the head, the nasal placodes develop from the ectoderm at each side of the frontonasal prominence. They then become more concave forming the nasal pit. The mesenchyme proliferates around the placode establishing the medial and lateral nasal prominences, while the nasal pit becomes deeper, forming the nasal cavities (Kim et al. 2004). The paranasal sinuses develop during late fetal life and in infancy as diverticula of the lateral nasal walls. The sinuses extend into the maxilla and reach their mature size in the early 20 s. In the neck, the laryngotracheal groove emerges from the primitive pharyngeal floor. The endoderm lining the laryngotracheal groove forms the epithelium and glands of the larynx, trachea, bronchi, and pulmonary lining epithelium (Panski 1982; Edgar et al. 2013). The primordial lung originates as a protrusion from the laryngotracheal groove of the ventral foregut endoderm, which then proliferates, forming two lung buds surrounded by the mesoderm in the primitive thoracic mesenchyme. Each lung bud develops into left and right lungs, respectively, by undergoing branching morphogenesis. This process is directed by signals between the epithelial endoderm and the surrounding mesoderm. Bronchial cartilage, smooth muscle, and other connective tissues are derived from the mesenchyme. As the lung progresses through its phases of development, it undergoes a complex series of epithelial-mesenchymal interactions regulated by homeobox genes, transcription factors, hormones, and growth factors (Chinoy 2003). During the postnatal phase, lung growth is geometric, and there is no increase in airway number. The alveoli increase in number after birth to reach the adult range of 300 million by 2 years of age and the surface area of 75 to $100 \mathrm{~m}^{2}$ by adulthood (Deutsch and Pinar 2002).

The result is a complex arrangement of organs and tissues that form the respiratory system, which is divided into two parts. The upper airway or upper respiratory tract includes the nose and nasal passages, paranasal sinuses, the oral cavity, the pharynx, and the portion of the larynx above the vocal cords. The nose and nasal cavity are the main external openings of the respiratory system. The oral cavity (mouth) acts as an alternative entry to the air, but it cannot filter the air of unwanted contaminants as the nose does. Although the upper respiratory tract represents the entryway to the conducting zone of the respiratory tract and plays an important role in trapping and removing particulate matter, in this review we will focus on the lower respiratory tract.

The lower airways, or lower respiratory tract, include the continuation of the conducting zone formed by the portion of the larynx below the vocal cords, trachea, and within the lungs, the bronchi, bronchioles, and the respiratory zone formed by respiratory bronchioles, alveolar ducts, and alveoli (Fig. 1A). On the surface of each alveolus, the oxygen from the atmosphere required for cellular respiration is exchanged for the carbon dioxide in the blood, which is released into the atmosphere.

\section{CELL TYPES IN THE LOWER RESPIRATORY TRACT}

Studies in mice during branching morphogenesis of the lung showed that the terminal buds contain a population of multipotent epithelial progenitors characterized by high levels of Nmyc, Sox9, and cyclin D1 proteins (Okubo et al. 2005). These multipotent cells will give rise to the major cell types of the conducting airways, including basal stem cells (Rock et al. 2009), neurosecretory cells (Kultschitsky or Kcells) (Becker and Silva 1981), ciliated cells, club cells, serous cells, goblet cells, intermediate cells, and brush cells (Reid and Jones 1980). The mu- 


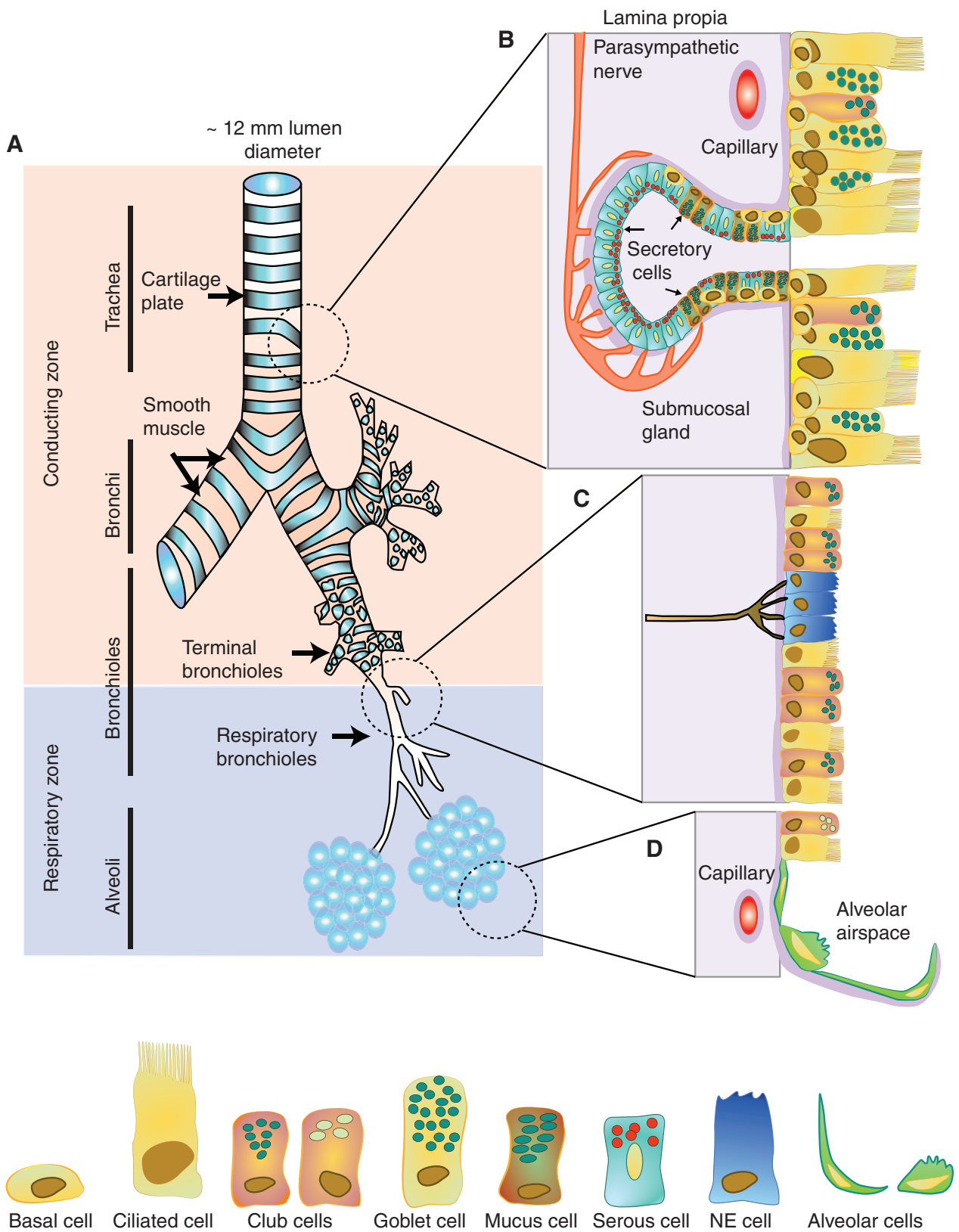

Figure 1. Schematic representation of the airway epithelium. (A) The lower respiratory tract, functionally can be divided into conducting and respiratory zones. The adult human trachea has an internal diameter of $\sim 12 \mathrm{~mm}$, cartilage plates, and smooth muscle. The trachea divides into right and left primary bronchi. A bronchus enters the lung at the hilum and then divides into bronchioles. After multiple bronchiolar branches ( $\sim 23$ generations in humans), at the end of each respiratory bronchiole, the alveoli are found. (B) The trachea and most proximal airways are lined by a pseudostratified epithelium formed by ciliated and secretory cells. Basal cells are located in this region and they can generate secretory and ciliated cell lineages. $(C)$ The small airways are lined by a simple cuboidal epithelium with fewer goblet cells, but are rich in club cells. $(D)$ The alveoli are made of type I and type II alveolar cells. 
cosa of the lower respiratory tract is a pseudostratified columnar epithelium with numerous ciliated and goblet cells (Fig. 1B). During differentiation, Notch signaling plays a major role in controlling cell fate commitment by selectively suppressing ciliation to allow secretory cell differentiation (Tsao et al. 2008). In fact, the use of Notch pathway inhibitors (e.g., $\mathrm{N}$ [(3,5-difluorophenyl)acetyl]-L-alanyl-2-phenyl] glycine-1,1-dimethylethyl ester [DAPT], a $\gamma$-secretase inhibitor that blocks the Notch pathway), has allowed researchers to direct the differentiation of airway cells into the ciliated epithelial cell lineage in culture (Konishi et al. 2016). In addition, the development of antibodies directed against members of this pathway can induce the transdifferentiation of goblet and club cells into ciliated cells. This observation may be useful for the development of therapeutic approaches to inhibit excess mucus production in airway diseases, including asthma (Lafkas et al. 2015).

The epithelium is supported by a collagenous lamina propia containing serous and $\mathrm{mu}-$ cus glands (Fig. 1B). The supporting lamina propia underneath the epithelium also contains elastin that plays a role in the elastic recoil of the trachea during inspiration and expiration. The smooth muscle of the airways plays a functional role in regulating airflow and is arranged in a complex spiral pattern that becomes progressively less prominent in the distal conducting airways.

The small airways (i.e., those $<2 \mathrm{~mm}$ in internal diameter), lack cartilaginous support and mucous glands. The epithelium progressively transitions to a less tall, simple cuboidal, less ciliated epithelium with few goblet cells but with an increased number of club cells (Fig. 1C). The division of respiratory bronchioles originates the alveolar ducts that connect to the alveolar sacs, which contain the alveoli. The alveoli are formed by two types of alveolar cells; type I alveolar cells are thin cells involved in the process of gas exchange and type II alveolar cells that secrete pulmonary surfactant (Fig. 1D).

Although the airway epithelium contains different types of cells, the ciliated cells and secretory cells in the surface epithelium and sub- mucosal glands contribute directly to mucociliary function.

\section{Secretory Cells}

The goblet cells are the principal secretory cells in the superficial epithelium of the tracheobronchial airway (Sleigh et al. 1988). They are intercalated among ciliated cells and connected to adjacent cells by tight junctions; together these cells form a selective barrier lining the respiratory tract. Of the cell population in the trachea, approximately $60 \%$ are ciliated cells and $20 \%$ are goblet cells. As the airways branch, the percentage of ciliated and goblet cells decreases, whereas the percentage of serous and club cells increases (Wanner et al. 1996; Davis and Randell 2001). The morphology of goblet cells is highly polarized, with the nucleus and other organelles localized to the base of the cell. Most of the apical cytoplasm contains membrane-bound secretory granules containing high molecular weight and gel-forming glycoproteins called mucins. In the small airways, serous and club cells contain small secretory granules and are thought to produce watery secretions. However, club cells can produce mucins and act as progenitors of goblet cells after bronchiolar injury (Sleigh et al. 1988; Zhu et al. 2008), suggesting there is significant functional overlap between these types of secretory cells.

The submucosa layer, present until the termination of the cartilaginous bronchioles, contains mixed seromucous glands that rapidly produce mucus in response to neural signals (Maggi et al. 1995). In the human trachea, the seromucous glands are found at a frequency of one gland per $\mathrm{mm}^{2}$ and are even more abundant as the airway lumens decrease in diameter until the termination of the cartilaginous bronchioles (Tos 1966; Wine and Joo 2004). The watery secretions from the serous glands humidify inspired air and, together with mucus from the goblet cells, comprise the bulk of the airway surface layer.

\section{Ciliated Cells}

Ciliated airway epithelial cells are elongated columnar cells that make limited contact with the 
basement membrane (Mercer et al. 1994). Unlike other cells types described above, ciliated cells are terminally differentiated epithelial cells (Rawlins and Hogan 2008). In the apical region, they have abundant mitochondria to ensure the availability of ATP to sustain ciliary motion mediated by the motor activity of axonemal dynein (Kikkawa 2013).

The differentiation program of ciliated cells starts during lung morphogenesis. The inhibition of Notch signaling activates a transcription program that includes the nuclear protein geminin coiled-coil containing (GMNC), which turns on MCIDAS expression (Zhou et al. 2015). MCIDAS encodes the transcriptional cofactor MULTICILIN (Stubbs et al. 2012; Boon et al. 2014), which induces the expression of FOXJ1, the master regulator for basal body docking, cilia formation, and motility (You et al. 2004; Vladar and Mitchell 2016).

Airway ciliated epithelial cells form $>100$ centrioles that will dock to the apical membrane and become the basal bodies that will allow the growth of the cilia (Sorokin 1968). Using live imaging combined with superresolution and electron microscopy, Al Jord et al. (2014) showed that in multiciliated ependymal cells only the daughter centriole contributes to amplification of basal bodies. Once the basal body has correctly positioned on the apical surface of the plasma membrane, axonemal extension occurs exclusively at the plus ends of the microtubules in a process mediated by the intraflagellar transport (IFT) system (Kozminski et al. 1993; Rosenbaum and Witman 2002). Proteins are loaded onto the IFT system at the ciliary base within the cytoplasm and transferred across the ciliary compartment border in a process known as ciliogenesis (Avidor-Reiss et al. 2004). As a result, fully differentiated ciliated airway epithelial cells have $>100$ cilia on their surface (Wanner et al. 1996).

\section{COMPONENTS OF THE MUCOCILIARY CLEARANCE APPARATUS}

The cilia that reach the surface of epithelium interact with a thin layer of fluid covering the air-facing surface, the airway surface layer
(ASL). The ASL includes a low viscosity periciliary layer (PCL) that lubricates airway surfaces and facilitates ciliary beating, and an overlaying mucous layer. The ASL may also include a surfactant layer to facilitate the spreading of mucus over the epithelial surface (Fig. 2A). Although the exact composition of the ASL is still unclear and a topic of debate, there is no doubt that the physical characteristics of the ASL are crucial to allow normal ciliary activity to maintain airway health.

\section{The Mucous Layer}

The major macromolecular constituents of the mucous layer are the mucin glycoproteins. The amino- and carboxy-terminal regions of these large proteins $\left(2-20 \times 10^{5} \mathrm{Da}\right)$ are lightly glycosylated but rich in cysteines that establish disulfide links between and among mucin monomers. In the central region, mucins contain multiple tandem repeats of serine and threonine, which are the sites for extensive $O$ linked glycosylation. The mucin proteins are encoded by MUC genes, and many of them are expressed in the airways, including the gel-forming mucins MUC5AC, MUC5B, MUC2, MUC8, and MUC19. The membrane-associated mucins, MUC1, MUC4, MUC11, MUC13, MUC15, MUC16, and MUC20, are also expressed on the surface of the airway epithelium. Muc7, a small mucin that lacks domains and does not form a gel, is secreted by a subset of serous cells in submucosal glands (Rose and Voynow 2006; Fan and Bobek 2010). In healthy airways, the goblet cells typically express MUC5AC, whereas mucosal cells of the submucosal glands express primarily MUC5B (Groneberg et al. 2002). The secretion of mucin can be stimulated by many factors, including paracrine and autocrine mediators, especially ATP (Chen et al. 2003; Rose and Voynow 2005). Increased production and secretion of mucins is a feature of many chronic airway diseases, including asthma, COPD, and cystic fibrosis (Rose and Voynow 2006)

The rheological properties of mucus (i.e., the capacity to undergo flow and deformation in response to the forces applied to it), and, therefore, the transportability of the mucous 

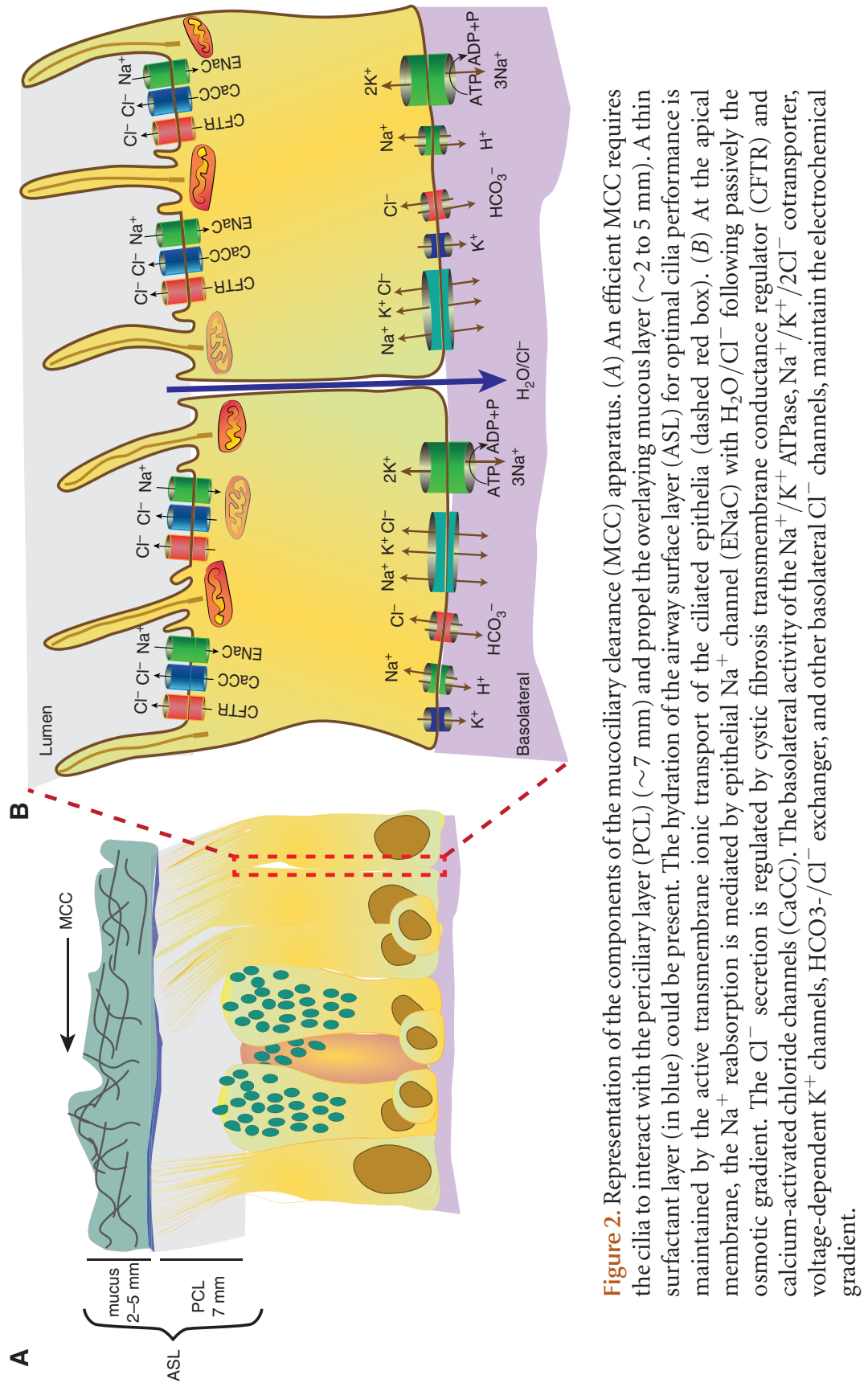
layer, are determined by the composition of the mucus and its hydration state. Normal mucus is composed of $\sim 1 \%$ mucins, $\sim 1 \%$ salt, $\sim 1 \%$ other proteins, and $\sim 97 \%$ water (Matthews et al. 1963; Hamed and Fiegel 2014). The hydration status is principally regulated by the export of $\mathrm{Cl}^{-}$through the cystic fibrosis transmembrane conductance regulator (CFTR) and $\mathrm{Ca}^{+2}$-activated chloride channels (CaCC), and by the influx of $\mathrm{Na}^{+}$through the epithelial $\mathrm{Na}^{+}$channel (ENaC) (Fig. 2B) (Tarran et al. 2005). By regulating these two processes, the epithelium controls the amount of water on the airway surface. Thus, in normal, healthy lungs, after secretion and hydration of mucins, a thin layer of mucus ( 2 to $5 \mu \mathrm{m}$ thick in the trachea) is formed above the cilia (Fig. 2A) from the bronchioles to the upper airway to protect the epithelium.

\section{Periciliary Layer and Surfactant}

The periciliary layer (PCL) is a polyanionic gel that has a height approximately equal to the height of the extended cilium $(7 \mu \mathrm{m}$, Fig. 2A) (Button et al. 2012). It contains the membrane-associated mucins (MUC1, MUC4, and MUC16) and other molecules including glycolipids (Randell and Boucher 2006; Button et al. 2012). It provides an efficient lubricating layer for ciliary beating, and serves as a barrier to restrict access of particles from the cell surface. As with the overlying mucus layer, the hydration state of the PCL reflects the balance of $\mathrm{Na}^{+}$and $\mathrm{Cl}^{-}$ion transport activities (Tarran et al. 2005). Maintenance of the depth of PCL is important for effective mucociliary clearance. If the PCL is not sufficiently hydrated, the mucus layer collapses on the cilia and they become trapped. (Sleigh et al. 1988; Randell and Boucher 2006). In patients with pseudohypoaldosteronism, with no active absorption of sodium in the airways because of mutations in $\mathrm{ENaC}$, the PCL is too deep. During the first year of life, children have frequent lower respiratory tract infections, possibly caused by inefficient MCC. Later in life, they have less frequent respiratory illness and, in a small sample, actually showed a faster than normal rate of MCC (Kerem et al. 1999).
Pulmonary surfactant is a surface-active material able to reduce surface tension at the alveolar and bronchiolar air-liquid interface. It originates mainly from the alveolar compartment, although specific components, including SP-A, SP-B, and SP-D, are also synthetized and secreted by nonciliated cells of the airway mucosa (Calkovska 2000). Some research groups have described a film of surfactants between the mucous and the PCL to permit the transfer of energy from the cilia to the mucus, while preventing ciliary entanglement in the mucus, thereby facilitating MCC (Girod de Bentzmann et al. 1993; Wanner et al. 1996). Surfactants could also be an integral component of the PCL, the mucus layer, or both.

\section{The Structure of Airway Cilia}

The adult lung is estimated to contain $\sim 3 \times$ $10^{12}$ total motile cilia. On average, a typical cilium is 6.5- to 7- $\mu \mathrm{m}$ long and has a diameter of $0.1 \mu \mathrm{m}$ (Wanner et al. 1996; Brekman et al. 2014). The core structure is the highly conserved $9+2$ axoneme that extends from the basal body in the apical region of ciliated cells into the PCL, with the cilia tips reaching the mucous layer of the airway lumen. The ciliary axoneme (Fig. 3A) consists of nine outer doublet microtubules surrounding two central singlet microtubules, the central pair (Satir and Christensen 2007). The outer doublets consist of a complete tubule, the A tubule, containing 13 tubulin subunits and a partial tubule, the $B$ tubule, containing 11 subunits. These doublets are connected to each other by a large protein complex, the nexin-dynein regulatory complex (N-DRC) (Heuser et al. 2009). The radial spokes project from the outer doublets toward the central-pair complex and play a role in both the mechanical stability of the axoneme and the regulation of ciliary activity. Attached to the A tubule are the multisubunit protein complexes, the inner and outer dynein arms (IDA and ODA, respectively) (Fig. 3A). Based on studies of other model systems, especially the flagella of the unicellular, biflagellate green alga, Chlamydomonas reinhardtii, it is known that the basic structure of ODA and IDA consists of one or 
A

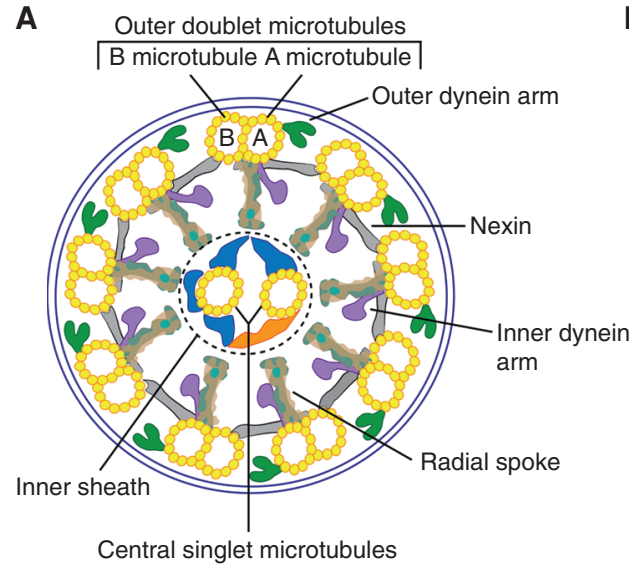

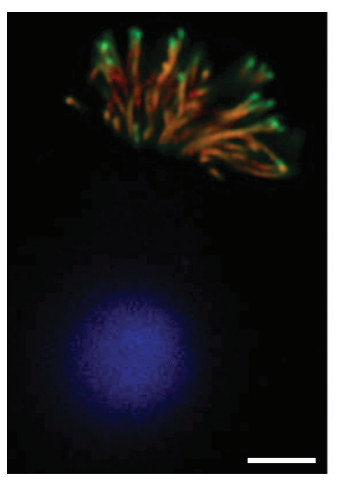

Ac-TUBULIN DNAH5 DNA
C

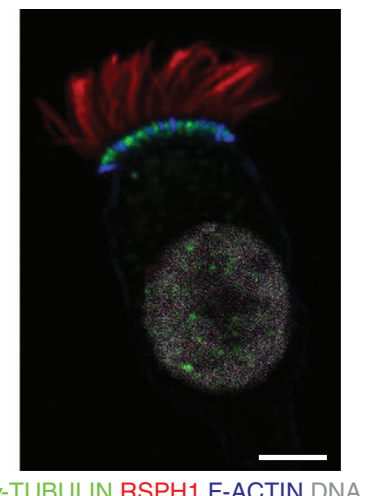

Figure 3. Axonemal structure of the cilia. $(A)$ The core structure of the cilia is the axoneme, as shown in the cross-sectional schematic diagram of a motile cilium displaying the characteristic $9+2$ pattern, nine peripheral doublets microtubules surrounding a central pair of single microtubules. The cilia contain multiple protein complexes, including dynein arms, radial spokes, nexin-dynein regulatory complex (N-DRC), and inner sheath that connect the microtubules to each other. $(B, C)$ Examples of single-cell immunofluorescence of human ciliated cells showing the localization of dynein heavy chain 5 (DNAH5) and radial spoke head 1 (RSPH1). Scale bars, $5 \mu \mathrm{m}$.

more dynein heavy chain (DHC) proteins (470 to $540 \mathrm{kDa}$ ), dynein intermediate chain proteins (57 to $140 \mathrm{kDa}$ ), and dynein light chain proteins (6 to $22 \mathrm{kDa}$ ) (Holzbaur and Vallee 1994). Detailed structural analysis of the DHC identified four distinct domains, including (1) the "tail," that acts as the cargo-binding domain, (2) the stalk region that binds to the microtubule, (3) a linker region, and (4) the head domain, which is the site where ATP is hydrolyzed to provide the force for ciliary beating (Kikkawa 2013) (for a more detailed structure of the axoneme, see Ishikawa 2016). In the human genome, there are 14 putative genes that encode for axonemal DHC (Yagi 2009). Although the detailed structure and composition of the dynein arms from human cilia is not as well described as that of Chlamydomonas, the development of specific antibodies has allowed researchers to determine that the distribution of the DHC proteins varies between the proximal and distal regions of the cilium (Fliegauf et al. 2005), as well as to localize other proteins to the ciliary axoneme (e.g., dynein heavy chain 5 [DNAH5] and radial spoke head 1 [RSPH1]) (Fig. 3B,C).
The activation of the DHC by ATP (Wanner et al. 1996; Porter and Sale 2000; Roberts et al. 2012) causes the doublet microtubules to slide with respect to one another. The presence of the interdoublet N-DRC and radial-spoke-centralpair interactions produce a controlled bending (Yeates et al. 1981; Houtmeyers et al. 1999), yielding a ciliary beat with an effective stroke and a recovery stroke within the same plane (Chilvers and O'Callaghan 2000). Studies in Chlamydomonas have provided evidence that the ODA are primarily responsible for adjusting ciliary beat frequency $(\mathrm{CBF})$, whereas the IDA are responsible for bend formation and waveform (Brokaw and Kamiya 1987).

Comparative genomic and proteomic studies have shown that the complete cilium contains $\sim 600$ proteins. Many of the ciliary proteins are highly conserved, specifically those that constitute the axonemal structure (Ostrowski et al. 2002; Avidor-Reiss et al. 2004; Lindskog et al. 2014). About one-third of these proteins have been correlated with a specific structure and function, and the majority of these studies were performed using Chlamydomonas flagella. Although there is tremendous conservation of 
both individual proteins and the overall axonemal structure between species, there are important structural differences between human cilia and Chlamydomonas flagella axonemes. For example, the ODA in Chlamydomonas is a threeheaded structure containing three dynein heavy chains $(\alpha, \beta, \gamma)$, whereas human ODA contains two dynein heavy chains (Pazour et al. 2006). Human cilia have three radial spokes, whereas Chlamydomonas flagella have two and a short structure known as the radial spoke stand-in (Lin et al. 2014). This structure corresponds to the base of the third radial spoke in human cilia. The overall arrangement of inner dynein arms within the $96 \mathrm{~nm}$ axoneme repeat and the central pair is remarkably similar, but there are slight differences in size and density between the two species (O'Toole et al. 2012). The cilia and flagella are also functionally different. The $12 \mu \mathrm{m}$ Chlamydomonas flagellum beats with two different waveforms at frequencies of up to $60 \mathrm{~Hz}$, enabling propulsion in opposite directions. Human airway cilia are approximately $7 \mu \mathrm{m}$ long and beat with a single waveform at lower frequencies $(10-20 \mathrm{~Hz})$ (Satir and Christensen 2007) to propel mucus out of the airways. The regulation of axonemal activity is also different between human airway cilia and other motile axonemes. For example, an increase in cAMP stimulates ciliary beat frequency in human cilia, while causing a decrease in Chlamydomonas (Wanner et al. 1996). Similarly, an increase in $\mathrm{Ca}^{2+}$ stimulates ciliary beat frequency in human cilia, while causing Chlamydomonas flagella to change from an asymmetric waveform to a symmetric waveform (Silflow and Lefebvre 2001). In spite of these differences, Chlamydomonas flagella have been an extremely useful model organism to study motile ciliopathies, and provided a wealth of biochemical, molecular, and structural information regarding the axoneme. The identification of a large number of mutations in Chlamydomonas that affect the assembly or function of specific axonemal structures (Porter and Sale 2000) have revealed that small defects in axoneme structure can severely impact cilia motility, and have helped to define the genetic defects responsible for PCD (e.g., Pennarun et al. 1999; see below).

\section{ROLE OF AIRWAY CILIA IN MCC AND ITS REGULATION}

In the mouse trachea, ciliary motion starts soon after birth. Analysis ex vivo of flow directionality in mouse tracheas measuring the net displacement of fluorescent microspheres by Francis et al. (2009), detected patches of ciliary motion as early as postnatal day 3 . This becomes uniform with maximal mucociliary flow by postnatal day 9. This study also showed that tracheal CBF was elevated immediately after birth compared to other time points. This could be a physiological mechanism to compensate for the lack of ciliary coordination and ensure the clearance of amniotic fluid from the lungs (Francis et al. 2009). In humans, ciliogenesis of the airways starts at 7 weeks of embryonic development (Moscoso et al. 1988) and is complete before birth; however, whether this ciliated epithelium is active and functional is unknown (Gaillard et al. 1989; Ostrowski 2002). Although it is interesting to note that neonatal respiratory distress is a common feature of PCD (Shapiro et al. 2016), the mechanism responsible for this is still unclear.

The cilia of the airways beat in a coordinated fashion that results in metachronal waves. Each cilium beats at the same frequency but in a phase-shifted manner with its neighbors along the axis of the effective stroke, and in phasesynchronously with the cilia in the perpendicular axis (Sanderson and Sleigh 1981; Brooks and Wallingford 2014). This generates a wave that travels across the epithelium propelling the overlying mucus in a cephalad direction. The basal CBF ranges between 10 and $20 \mathrm{~Hz}$ (Satir and Christensen 2007), yielding a mucociliary clearance velocity of $\sim 5.5 \mathrm{~mm} / \mathrm{min}$ (Hofmann and Asgharian 2003). Studies in mouse airways and Xenopus laevis showed that, to establish a coordinated ciliary beat pattern, the cilia need to be physically oriented according to the tissue axis, which is specified by the planar cell polarity pathway (Vladar et al. 2015). This orientation allows the cilia to propagate the wave of ciliary beat using the underlying cytoskeletal network. Actin bridges, connecting neighboring basal bodies, are necessary for intracellular 
propagation of the metachronal wave (Werner et al. 2011), whereas cytoplasmic microtubules that emanate from the basal foot cap, anchor the basal foot. These interactions are required for the maintenance of local coordination of the cilia (Werner et al. 2011; Clare et al. 2014). In human airways, a similar mechanism is likely responsible for controlling the orientation of the cilia, which is crucial for coordinated ciliary beating and effective MCC.

Although the mechanisms that regulate basal CBF have been studied extensively (Sanderson and Sleigh 1981; Sleigh et al. 1988; Satir and Sleigh 1990), they are still unclear. However, the identification of factors that enhance CBF have been useful for the development of therapies to improve MCC in patients with chronic airway diseases. For example, CBF can be stimulated by $\beta$-adrenergic agonists (Bennett 2002), intracellular increase of nucleotides, including cAMP and cyclic guanosine monophosphate (cGMP) (Satir and Sleigh 1990; Wanner et al. 1996; Wyatt 2015), and an intracellular increase of $\mathrm{Ca}^{2+}$. Ciliated cells express multiple bitter taste receptors (R2T) that localize at different places along the cilium, making it a chemosensory organelle. These receptors sense noxious stimuli and stimulate $\mathrm{CBF}$ in a $\mathrm{Ca}^{2+}$-dependent manner (Shah et al. 2009). Studies performed in human nasal epithelial cultures showed that extracellular adenosine and uridine nucleotides, acting through the $\mathrm{P} 2 \mathrm{Y} 2$ receptor, are one of the most potent $\mathrm{CBF}$ agonists. Interestingly, ATP produces a rapid increase in CBF, but the hydrolysis of ATP to ADP results in a more prolonged response through the activation of $\mathrm{A} 2 \mathrm{~B}$ receptor (Morse et al. 2001). ATP is constantly released during normal and induced mechanical stimulation of the airways (Button et al. 2007), and helps maintain proper hydration of the mucus layer in addition to stimulating CBF (Button et al. 2013).

$\mathrm{CBF}$ is temperature dependent (Clary-Meinesz et al. 1992; Sears et al. 2015); because there is an optimal temperature for the enzymatic hydrolysis of ATP by dynein, low temperatures decrease CBF. The manipulation of temperature is a useful tool to study the relationship between $\mathrm{CBF}$ and mucociliary transport in con- trolled systems of airway cultures (Sears et al. 2015). CBF can also be affected by $\mathrm{pH}$ changes. Although the human airway can tolerate variations in local $\mathrm{pH}$ (6.9 to 7.0) induced during the respiratory cycle (Clary-Meinesz et al. 1998), intracellular alkalization stimulates, whereas intracellular acidification decreases, CBF (Sutto et al. 2004). Cigarette smoke is known to be a major risk factor for the development of COPD. Studies in humans and mice have shown that this common air pollutant significantly decreases CBF (Elliott et al. 2007; Simet et al. 2010), increases mucus secretion (Gensch et al. 2004), and leads to the generation of reactive oxygen species that reduces the number of ciliated cells (Milara et al. 2012).

\section{MEASUREMENT OF MCC}

The standard measurement of MCC rates in humans requires the inhalation of a nonpermeating radiolabeled marker that deposits on the airway surface. This method assumes that the marker moves out of the lung at the same rate as the airway secretions in which it is immersed. The short half-life isotope ${ }^{99 \mathrm{~m}}$ technetium $\left({ }^{99 \mathrm{~m}} \mathrm{Tc}\right)$ is used to label the inhaled marker, which is then monitored by $\gamma$ camera over periods of 1 to $24 \mathrm{hr}$ (Bennett et al. 2013). Although this method provides a direct measurement of MCC, it is not well suited for routine experimental studies. Various methods have been used to study MCC in many different animal models, including sheep, dogs, pigs, and mice (Sabater et al. 1999; Foster et al. 2001; Lay et al. 2003; Bhashyam et al. 2012; Hoegger et al. 2014). The use of genetically modified mouse models has provided a valuable tool to study the role of motile cilia; however, the small size of the mouse airways has made measurements of in vivo clearance rates using radioactivity challenging (Foster et al. 2001; Bhashyam et al. 2012). Other investigators studying mouse models have recorded the movement of fluorescent particles along the trachea or nasopharynx of the mouse (e.g., Ostrowski et al. 2010) or measured the recovery of fluorescent beads from the lungs after a specified time (Look et al. 2001; Grubb et al. 2016). Alternatively, investigators have 
also used ex vivo preparations of trachea or bronchi to investigate MCC (Cooper et al. 2013; Francis and Lo 2013). Although these studies provide valuable information, the techniques are invasive and the system is not easy to manipulate.

The development of well-differentiated human airway cultures (Gray et al. 1996; Matsui et al. 1998b), that showed coordinated ciliary activity, provided a powerful tool to study the integrated process of MCC, including cilia coordination and transport. Air-liquid interface cultures of human airway cells with areas of coordinated ciliary activity spontaneously transport mucus in a circular pattern, forming what is commonly referred to as mucus hurricanes, which have been useful for the study of CF (Matsui et al. 1998a; Tarran et al. 2005; Button and Boucher 2008; Zhang et al. 2009). However, in these cultures, the overall height of the mucus layer is variable and the areas of coordination are of various sizes. To avoid these disadvantages, a modified culture system was developed by gluing a $15-\mathrm{mm}$ plastic cylinder in the center of a $30-\mathrm{mm}$ millicell culture insert, generating a mucociliary transport device (MCTD), in which human airway cells were seeded and allowed to differentiate (Sears et al. 2015). In this arrangement, cilia coordinate their activity to transport mucus in a continuous circular path around the culture track. This culture system enables the study of mucociliary transport, the visualization of ciliary coordination over time, and the evaluation of different factors that affect the rate of mucociliary transport. For example, using this system, it was shown that increasing CBF by increasing temperature produced a linear increase in mucociliary transport speed (Sears et al. 2015).

\section{Factors Involved in MCC}

A number of studies measuring the basal rates of MCC in healthy nonsmoking subjects showed that physiological factors as age, sex, posture, sleep, and exercise affect MCC (Houtmeyers et al. 1999). Efficient MCC is optimal at core temperature and $100 \%$ relative humidity conditions (Williams et al. 1996). Under low temper- ature and humidity, the depth of the PCL is reduced, ciliary cells decrease their activity, and MCC slows, potentially allowing for increased bacterial infection. Conversely, high humidity enhances MCC (Clary-Meinesz et al. 1992; Daviskas et al. 1995; Oozawa et al. 2012). The ciliary factors that affect MCC rate include the number and length of the cilia, the coordination of ciliary beating, and the ciliary beat frequency and amplitude, which together determine the maximal velocity at the tips of the cilia and, therefore, the forward velocity of the mucous layer (King 2006). However, a faster ciliary beat frequency does not necessarily imply improvement of MCC rates, as a lack of coordination can severely affect ciliary transport (see below). Serous factors include mucus rheology and hydration. If the mucous layer is too thick because of mucin hypersecretion, as in asthma (Kuyper et al. 2003), or the mucus is too viscous because of dehydration, as in CF (Knowles and Boucher 2002), then the rate of MCC decreases because the cilia are not able to beat properly. The transference of momentum between the cilia and the mucous layer during their forward stroke while minimally interacting with the mucus during the return is disrupted. As mentioned above, another important factor in maintaining normal MCC is the release of ATP onto the airway lumen to maintain or increase ASL hydration and accelerate CBF, thus promoting lung health (Button et al. 2007).

Most of the current knowledge about how MCC is endogenously regulated at the organ and cellular level came from studies designed to explore the pathogenesis of chronic lung diseases. For example, studies of CF have highlighted the role of ion transport and airway hydration in MCC. Studies of asthma and COPD have led to a better understanding of the effects of chronic inflammation and mucus hypersecretion (Kuyper et al. 2003; Ramos et al. 2014). Studies of the effect of cigarette smoke on cilia performance provided insight into its effect on cilia length and its consequences for COPD (Gensch et al. 2004; Elliott et al. 2007; Simet et al. 2010; Milara et al. 2012; Brekman et al. 2014). Finally, studies of PCD not only clearly showed the key role of ciliary motility in MCC, but also delin- 
X.M. Bustamante-Marin and L.E. Ostrowski

eated the physiological role that motile cilia play elsewhere in the body (Fliegauf et al. 2007).

\section{Cilia and MCC in PCD}

Primary ciliary dyskinesia is a genetically heterogeneous autosomal-recessive disorder with an incidence of 1:15,000 live births. This disorder affects the proper biogenesis, assembly and activity of cilia, resulting in dysfunction of motile cilia and impairment of MCC. The clinical features include situs inversus in 50\% of the patients, infertility, and chronic ear infections. The disease affects the entire respiratory tract, with symptoms appearing soon after birth. Over $80 \%$ of PCD patients experience neonatal respiratory distress during the first $24 \mathrm{~h}$ of life (Shapiro et al. 2016). Because of impaired MCC, mucus and pathogens accumulate in the upper and lower airways causing year-round daily cough and nasal congestion, chronic sinusitis, and recurrent lower respiratory infections, leading to bronchiectasis, and, in severe cases, lung transplantation.

Currently, mutations in 33 genes have been associated with PCD (Zariwala et al. 2007; Shapiro et al. 2016). The genetic variants of PCD can affect the pattern of ciliary beating, CBF, or both (Raidt et al. 2014). The most prevalent ultrastructural defect in the ciliary axoneme of patients with PCD (as evaluated by transmission electron microscopy), is the lack of ODAs (Fig. 4). The structural defect in the ODAs can be caused by mutations in genes encoding proteins that are structural components of the ODA (e.g., DNAH5 and DNAH1) or mutation in genes encoding for ODA-docking complex components (e.g., CCDC14 and CCDC151). Consistent with evidence that ODAs primarily control CBF, PCD patients with ODA defects have significantly lower CBF (Raidt et al. 2014).

Other PCD-causing mutations have been identified in genes that code for proteins involved in the cytoplasmic assembly of dynein arms (e.g., SPAG1, DNAF1-3, and DYXC1). In these patients, the ciliary axoneme lacks ODA and IDA; as a result, they typically have completely immotile cilia (Fig. 4) (Knowles et al. 2013; Tarkar et al. 2013). Mutations have also been identified in genes that encode for radial spoke components, including RSPH1, RSPH4A, and RSPH9 (Fig. 4). When examined by transmission electron microscopy, the majority of cilia from these patients appear normal;

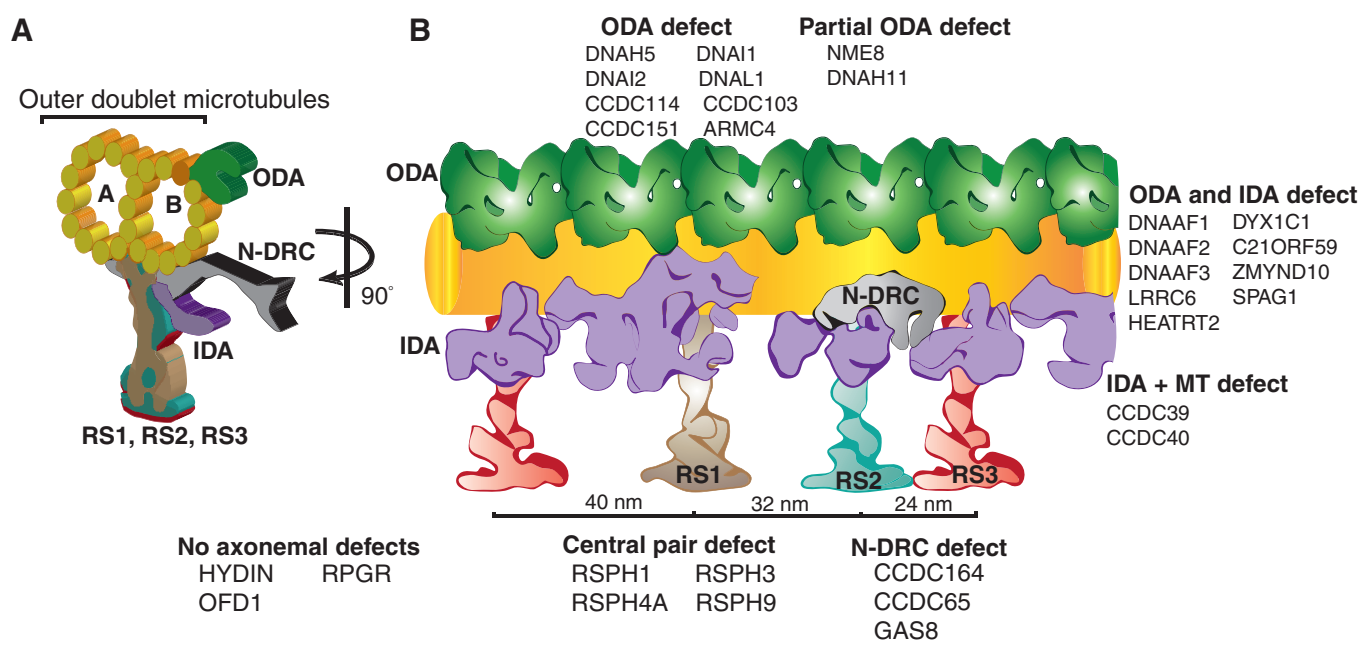

Figure 4. Mutations found in PCD patients and their association to ultrastructural axonemal defects. Schematic representation of the axoneme in $(A)$ cross-sectional, and $(B)$ the longitudinal views of the $96 \mathrm{~nm}$ repeat. Mutations in $>30$ genes have been identified in patients with PCD. The affected gene and the corresponding axoneme defect are listed. 
a subset of ciliary axonemes display abnormalities of the central pair (Knowles et al. 2014). In these patients, the CBF is in the normal range but parameters related to the amplitude and velocity of cilia bend are affected; as a result, ciliary beat is abnormal with a circular beat pattern (Castleman et al. 2009; Knowles et al. 2014). Analysis of isolated cilia from a patient with RSPH1 mutations by cryoelectron tomography revealed that, although the RSPH1 mutation resulted in the loss of radial spoke heads 1 and 2, the third radial spoke head remained intact (Lin et al. 2014). Interestingly, patients with RSPH1 mutations have less severe clinical features of disease than typical PCD patients (Knowles et al. 2014). These data suggest that, although mutations in RSPH1 cause disease, the atypical circular beat pattern may be able to provide a low level of MCC. In addition, PCD may occur without discernible axonemal ultrastructural defects. For example, cilia from patients with mutations in genes that encode for HYDIN, a large central-pair apparatus protein, or DNAH11, an outer arm heavy chain, appeared normal by TEM (Fig. 4) (Knowles et al. 2012; Olbrich et al. 2012). However, immunofluorescence analysis have localized DNAH11 to the proximal region of the cilia and TEM tomography analysis of cilia from a patient carrying DNAH11 mutations detected a partial reduction of ODAs in the proximal but not distal regions (Dougherty et al. 2016). This new observation highlights the difficulties of diagnosing PCD by TEM, and shows the importance of using other techniques, including whole exome sequencing, to obtain a definitive diagnosis. Cilia from patients with DNAH11 mutations have a stiff but typically hyperkinetic beat frequency (Schwabe et al. 2008), while patients with HYDIN mutations have a stiff but typically reduced beat frequency. In these cases, although the axonemal structure appears normal and ciliary beat frequency ranges from immotile to hyperkinetic, the abnormal ciliary motion results in inefficient MCC. Future studies will no doubt uncover mutations in additional genes that cause PCD.

As expected, PCD patients show markedly reduced tracheobronchial clearance compared with healthy individuals (Walker et al. 2014; Munkholm et al. 2015). To compensate for the deficient mucociliary transport, patients with PCD rely almost entirely on cough clearance to remove secretions from their bronchial airways (Noone et al. 1999). Although the ability to clear mucus by coughing partially compensates for the lack of effective MCC, PCD patients suffer from chronic, life-long, respiratory disease, and additional research into new therapies is warranted.

\section{CONCLUSIONS AND FUTURE PERSPECTIVES}

In the last decade, important advances have been made in understanding the structure of the cilia as well as the regulation of ciliary activity. The standardization of techniques to measure MCC in humans in health and disease, the development of mouse models of PCD and other airway diseases, and the development of welldifferentiated culture systems have yielded considerable knowledge about the role of cilia in MCC. The studies performed in patients with PCD highlight the crucial role that ciliary motility plays in MCC, and have identified many mutations that can affect ciliary function. However, there are still many important questions remaining, including (1) How are the cilia of the airway coordinated at both the cellular and organelle level? (2) What are the proteins localized at the tip of the cilia, and how do they interact with the mucous layer? (3) What is the contribution of the ciliated cells to the establishment and maintenance of the PCL? The collaborative efforts of many scientists from different fields will be required to uncover the answers to these questions.

\section{REFERENCES}

${ }^{*}$ Reference is also in this collection.

Al Jord A, Lemaitre AI, Delgehyr N, Faucourt M, Spassky N, Meunier A. 2014. Centriole amplification by mother and daughter centrioles differs in multiciliated cells. Nature 516: 104-107.

Avidor-Reiss T, Maer AM, Koundakjian E, Polyanovsky A, Keil T, Subramaniam S, Zuker CS. 2004. Decoding cilia function: Defining specialized genes required for compartmentalized cilia biogenesis. Cell 117: 527-539. 
X.M. Bustamante-Marin and L.E. Ostrowski

Becker KL, Silva OL. 1981. Hypothesis: The bronchial Kulchitsky $(\mathrm{K})$ cell as a source of humoral biologic activity. Med Hypotheses 7: 943-949.

Bennett WD. 2002. Effect of $\beta$-adrenergic agonists on mucociliary clearance. J Allergy Clin Immunol 110: S291-S297.

Bennett WD, Laube BL, Corcoran T, Zeman K, Sharpless G, Thomas K, Wu J, Mogayzel PJ Jr, Pilewski J, Donaldson S. 2013. Multisite comparison of mucociliary and cough clearance measures using standardized methods. JAerosol Med Pulm Drug Deliv 26: 157-164.

Bhashyam AR, Mogayzel PJ Jr, McGrath-Morrow S, Neptune E, Malinina A, Fox J, Laube BL. 2012. A pilot study to examine the effect of chronic treatment with immunosuppressive drugs on mucociliary clearance in a vagotomized murine model. PloS ONE 7: e45312.

Boon M, Wallmeier J, Ma L, Loges NT, Jaspers M, Olbrich H, Dougherty GW, Raidt J, Werner C, Amirav I, et al. 2014 MCIDAS mutations result in a mucociliary clearance disorder with reduced generation of multiple motile cilia. Nat Commun doi: 10.1038/ncomms5418.

Brekman A, Walters MS, Tilley AE, Crystal RG. 2014. FOXJ1 prevents cilia growth inhibition by cigarette smoke in human airway epithelium in vitro. Am J Respir Cell Mol Biol 51: 688-700.

Brokaw CJ, Kamiya R. 1987. Bending patterns of Chlamydomonas flagella. IV: Mutants with defects in inner and outer dynein arms indicate differences in dynein arm function. Cell Motil Cytoskeleton 8: 68-75.

Brooks ER, Wallingford JB. 2014. Multiciliated cells: A review. Curr Biol 24: R973-R982.

Button B, Boucher RC. 2008. Role of mechanical stress in regulating airway surface hydration and mucus clearance rates. Respir Physiol Neurobiol 163: 189-201.

Button B, Picher M, Boucher RC. 2007. Differential effects of cyclic and constant stress on ATP release and mucociliary transport by human airway epithelia. J Physiol 580: 577-592.

Button B, Cai LH, Ehre C, Kesimer M, Hill DB, Sheehan JK, Boucher RC, Rubinstein M. 2012. A periciliary brush promotes the lung health by separating the mucus layer from airway epithelia. Science 337: 937-941.

Button B, Okada SF, Frederick CB, Thelin WR, Boucher RC 2013. Mechanosensitive ATP release maintains proper mucus hydration of airways. Sci Signal 6: ra46.

Calkovska A. 2000. Pulmonary surfactant in the respiratory tract. Cesk Fysiol 49: 145-151.

Castleman VH, Romio L, Chodhari R, Hirst RA, de Castro SC, Parker KA, Ybot-Gonzalez P, Emes RD, Wilson SW, Wallis C, et al. 2009. Mutations in radial spoke head protein genes RSPH9 and RSPH4A cause primary ciliary dyskinesia with central-microtubular-pair abnormalities. Am J Hum Genet 84: 197-209.

Chen Y, Thai P, Zhao YH, Ho YS, DeSouza MM, Wu R. 2003. Stimulation of airway mucin gene expression by interleukin (IL)-17 through IL-6 paracrine/autocrine loop. J Biol Chem 278: 17036-17043.

Chilvers MA, O'Callaghan C. 2000. Analysis of ciliary beat pattern and beat frequency using digital high speed imaging: Comparison with the photomultiplier and photodiode methods. Thorax 55: 314-317.
Chinoy MR. 2003. Lung growth and development. Front Biosci 8: d392-d415.

Clare DK, Magescas J, Piolot T, Dumoux M, Vesque C, Pichard E, Dang T, Duvauchelle B, Poirier F, Delacour D. 2014. Basal foot MTOC organizes pillar MTs required for coordination of beating cilia. Nat Commun 5: 4888.

Clary-Meinesz CF, Cosson J, Huitorel P, Blaive B. 1992. Temperature effect on the ciliary beat frequency of human nasal and tracheal ciliated cells. Biol Cell 76: 335-338.

Clary-Meinesz C, Mouroux J, Cosson J, Huitorel P, Blaive B. 1998. Influence of external $\mathrm{pH}$ on ciliary beat frequency in human bronchi and bronchioles. Eur Respir J11: 330333.

Cooper JL, Quinton PM, Ballard ST. 2013. Mucociliary transport in porcine trachea: Differential effects of inhibiting chloride and bicarbonate secretion. Am J Physiol Lung Cell Mol Physiol 304: L184-L190.

Davis CW, Randell SH. 2001. Airway goblet and mucous cells: Identical, similar, or different? In Cilia and mucus: From development to respiratory defense (ed. Salatheed M), pp. 195-210. Marcel Dekker, New York.

Daviskas E, Anderson SD, Gonda I, Chan HK, Cook P, Fulton R. 1995. Changes in mucociliary clearance during and after isocapnic hyperventilation in asthmatic and healthy subjects. Eur Respir J 8: 742-751.

Deutsch GH, Pinar H. 2002. Prenatal lung development. In Chronic obstructive lung diseases (ed. Voelkel NCF, MacNee W), pp. xi, 428. BC Decker, Hamilton, Ontario

Dickson RP, Huffnagle GB. 2015. The lung microbiome: New principles for respiratory bacteriology in health and disease. PLoS Pathog 11: e1004923.

Dougherty GW, Loges NT, Klinkenbusch JA, Olbrich H, Pennekamp P, Menchen T, Raidt J, Wallmeier J, Werner C, Westermann C, et al. 2016. DNAH11 localization in the proximal region of respiratory cilia defines distinct outer dynein arm complexes. Am J Respir Cell Mol Biol 55: 213-224.

Edgar R, Mazor Y, Rinon A, Blumenthal J, Golan Y, Buzhor E, Livnat I, Ben-Ari S, Lieder I, Shitrit A, et al. 2013. LifeMap discovery: The embryonic development, stem cells, and regenerative medicine research portal. PloS ONE 8: e66629.

Elliott MK, Sisson JH, Wyatt TA. 2007. Effects of cigarette smoke and alcohol on ciliated tracheal epithelium and inflammatory cell recruitment. Am J Respir Cell Mol Biol 36: $452-459$.

Fan H, Bobek LA. 2010. Regulation of human MUC7 mucin gene expression by cigarette smoke extract or cigarette smoke and pseudomonas aeruginosa lipopolysaccharide in human airway epithelial cells and in MUC7 transgenic mice. Open Respir Med J 4: 63-70.

Fliegauf M, Olbrich H, Horvath J, Wildhaber JH, Zariwala MA, Kennedy M, Knowles MR, Omran H. 2005. Mislocalization of DNAH5 and DNAH9 in respiratory cells from patients with primary ciliary dyskinesia. Am J Respir Crit Care Med 171: 1343-1349.

Fliegauf M, Benzing T, Omran H. 2007. When cilia go bad: Cilia defects and ciliopathies. Nat Rev Mol Cell Biol 8: 880-893.

Foster WM, Walters DM, Longphre M, Macri K, Miller LM. 2001. Methodology for the measurement of mucociliary 
function in the mouse by scintigraphy. J Appl Physiol 90: 1111-1117.

Francis R, Lo C. 2013. Ex vivo method for high resolution imaging of cilia motility in rodent airway epithelia. J Vis Exp doi: $10.3791 / 50343$.

Francis RJ, Chatterjee B, Loges NT, Zentgraf H, Omran H, Lo CW. 2009. Initiation and maturation of cilia-generated flow in newborn and postnatal mouse airway. Am J Physiol Lung Cell Mol Physiol 296: L1067-L1075.

Gaillard DA, Lallement AV, Petit AF, Puchelle ES. 1989. In vivo ciliogenesis in human fetal tracheal epithelium. Am J Anat 185: 415-428.

Gensch E, Gallup M, Sucher A, Li D, Gebremichael A, Lemjabbar H, Mengistab A, Dasari V, Hotchkiss J, Harkema J, et al. 2004. Tobacco smoke control of mucin production in lung cells requires oxygen radicals AP-1 and JNK. J Biol Chem 279: 39085-39093.

Girod de Bentzmann S, Pierrot D, Fuchey C, Zahm JM, Morancais JL, Puchelle E. 1993. Distearoyl phosphatidylglycerol liposomes improve surface and transport properties of CF mucus. Eur Respir J 6: 1156-1161.

Gray TE, Guzman K, Davis CW, Abdullah LH, Nettesheim P. 1996. Mucociliary differentiation of serially passaged normal human tracheobronchial epithelial cells. Am Respi Cell Mol Biol 14: 104-112.

Groneberg DA, Eynott PR, Oates T, Lim S, Wu R, Carlstedt I, Nicholson AG, Chung KF. 2002. Expression of MUC5AC and MUC5B mucins in normal and cystic fibrosis lung. Respir Med 96: 81-86.

Grubb BR, Livraghi-Butrico A, Rogers TD, Yin W, Ostrowski LE. 2016. Reduced mucociliary clearance in old mice is associated with a decrease in Muc5B mucin. Am J Physiol Lung Cell Mol Physiol doi: 10.1152/ajplung. 00015.2016.

Hamed R, Fiegel J. 2014. Synthetic tracheal mucus with native rheological and surface tension properties. J Biomed Mater Res A 102: 1788-1798.

Heuser T, Raytchev M, Krell J, Porter ME, Nicastro D. 2009. The dynein regulatory complex is the nexin link and a major regulatory node in cilia and flagella. J Cell Biol 187: 921-933.

Hoegger MJ, Awadalla M, Namati E, Itani OA, Fischer AJ, Tucker AJ, Adam RJ, McLennan G, Hoffman EA, Stoltz DA, et al. 2014. Assessing mucociliary transport of single particles in vivo shows variable speed and preference for the ventral trachea in newborn pigs. Proc Natl Acad Sci 111: $2355-2360$.

Hofmann W, Asgharian B. 2003. The effect of lung structure on mucociliary clearance and particle retention in human and rat lungs. Toxicol Sci 73: 448-456.

Holzbaur EL, Vallee RB. 1994. Dyneins: Molecular structure and cellular function. Annu Rev Cell Biol 10: 339-372.

Houtmeyers E, Gosselink R, Gayan-Ramirez G, Decramer M. 1999. Regulation of mucociliary clearance in health and disease. Eur Respir J 13: 1177-1188.

* Ishikawa T. 2016. Axoneme structure from motile cilia. Cold Spring Harb Perspect Biol doi: 10.1101/cshperspect. a028076

Kerem E, Bistritzer T, Hanukoglu A, Hofmann T, Zhou Z, Bennett W, MacLaughlin E, Barker P, Nash M, Quittell L, et al. 1999. Pulmonary epithelial sodium-channel dys- function and excess airway liquid in pseudohypoaldosteronism. N Engl J Med 341: 156-162.

Kikkawa M. 2013. Big steps toward understanding dynein. J Cell Biol 202: 15-23.

Kim CH, Park HW, Kim K, Yoon JH. 2004. Early development of the nose in human embryos: A stereomicroscopic and histologic analysis. Laryngoscope 114: $1791-$ 1800.

King M. 2006. Physiology of mucus clearance. Paediatr Respir Rev 7: S212-S214.

Knowles MR, Boucher RC. 2002. Mucus clearance as a primary innate defense mechanism for mammalian airways. J Clin Invest 109: 571-577.

Knowles MR, Leigh MW, Carson JL, Davis SD, Dell SD, Ferkol TW, Olivier KN, Sagel SD, Rosenfeld M, Burns KA, et al. 2012. Mutations of DNAH11 in patients with primary ciliary dyskinesia with normal ciliary ultrastructure. Thorax 67: 433-441.

Knowles MR, Ostrowski LE, Loges NT, Hurd T, Leigh MW, Huang L, Wolf WE, Carson JL, Hazucha MJ, Yin W, et al. 2013. Mutations in SPAG1 cause primary ciliary dyskinesia associated with defective outer and inner dynein arms. Am J Hum Genet 93: 711-720.

Knowles MR, Ostrowski LE, Leigh MW, Sears PR, Davis SD, Wolf WE, Hazucha MJ, Carson JL, Olivier KN, Sagel SD, et al. 2014. Mutations in RSPH1 cause primary ciliary dyskinesia with a unique clinical and ciliary phenotype. Am J Respir Crit Care Med 189: 707-717.

Konishi S, Gotoh S, Tateishi K, Yamamoto Y, Korogi Y, Nagasaki T, Matsumoto H, Muro S, Hirai T, Ito I, et al. 2016. Directed induction of functional multi-ciliated cells in proximal airway epithelial spheroids from human pluripotent stem cells. Stem Cell Rep 6: 18-25.

Kozminski KG, Johnson KA, Forscher P, Rosenbaum JL. 1993. A motility in the eukaryotic flagellum unrelated to flagellar beating. Proc Natl Acad Sci 90: 5519-5523.

Kuyper LM, Paré PD, Hogg JC, Lambert RK, Ionescu D, Woods R, Bai TR. 2003. Characterization of airway plugging in fatal asthma. Am J Med 115: 6-11.

Lafkas D, Shelton A, Chiu C, de Leon Boenig G, Chen Y, Stawicki SS, Siltanen C, Reichelt M, Zhou M, Wu X, et al. 2015. Therapeutic antibodies reveal Notch control of transdifferentiation in the adult lung. Nature 528: $127-$ 131.

Lay JC, Stang MR, Fisher PE, Yankaskas JR, Bennett WD. 2003. Airway retention of materials of different solubility following local intrabronchial deposition in dogs. J Aerosol Med 16: 153-166.

Lin J, Yin W, Smith MC, Song K, Leigh MW, Zariwala MA, Knowles MR, Ostrowski LE, Nicastro D. 2014. Cryo-electron tomography reveals ciliary defects underlying human RSPH1 primary ciliary dyskinesia. Nat Commun doi: $10.1038 /$ ncomms6727.

Lindskog C, Fagerberg L, Hallström B, Edlund K, Hellwig B, Rahnenführer J, Kampf C, Uhlén M, Pontén F, Micke P. 2014. The lung-specific proteome defined by integration of transcriptomics and antibody-based profiling. FASEB J 28: 5184-5196.

Look DC, Walter MJ, Williamson MR, Pang L, You Y, Sreshta JN, Johnson JE, Zander DS, Brody SL. 2001. Effects of paramyxoviral infection on airway epithelial cell Foxj1 
expression, ciliogenesis, and mucociliary function. Am J Pathol 159: 2055-2069.

Maggi CA, Giachetti A, Dey RD, Said SI. 1995. Neuropeptides as regulators of airway function: Vasoactive intestinal peptide and the tachykinins. Physiol Rev 75: 277-322.

Matsui H, Grubb BR, Tarran R, Randell SH, Gatzy JT, Davis CW, Boucher RC. 1998a. Evidence for periciliary liquid layer depletion, not abnormal ion composition, in the pathogenesis of cystic fibrosis airways disease. Cell 95: 1005-1015.

Matsui H, Randell SH, Peretti SW, Davis CW, Boucher RC. 1998b. Coordinated clearance of periciliary liquid and mucus from airway surfaces. J Clin Invest 102: 11251131.

Matthews LW, Spector S, Lemm J, Potter JL. 1963. Studies on pulmonary secretions. Am Rev Respir Dis 88: 199-204.

Mercer RR, Russell ML, Roggli VL, Crapo JD. 1994. Cell number and distribution in human and rat airways. Am J Respir Cell Mol Biol 10: 613-624.

Milara J, Armengot M, Bañuls P, Tenor H, Beume R, Artigues E, Cortijo J. 2012. Roflumilast $N$-oxide, a PDE4 inhibitor, improves cilia motility and ciliated human bronchial epithelial cells compromised by cigarette smoke in vitro. Br J Pharmacol 166: 2243-2262.

Morse DM, Smullen JL, Davis CW. 2001. Differential effects of UTP, ATP, and adenosine on ciliary activity of human nasal epithelial cells. Am J Physiol Cell Physiol 280: C1485-C1497.

Moscoso GJ, Driver M, Codd J, Whimster WF. 1988. The morphology of ciliogenesis in the developing fetal human respiratory epithelium. Pathol Res Pract 183: 403411.

Munkholm M, Nielsen KG, Mortensen J. 2015. Clinical value of measurement of pulmonary radioaerosol mucociliary clearance in the work up of primary ciliary dyskinesia. EJNMMI Res 5: 118.

Noone PG, Bennett WD, Regnis JA, Zeman KL, Carson JL, King M, Boucher RC, Knowles MR. 1999. Effect of aerosolized uridine $-5^{\prime}$-triphosphate on airway clearance with cough in patients with primary ciliary dyskinesia. Am J Respir Crit Care Med 160: 144-149.

Okubo T, Knoepfler PS, Eisenman RN, Hogan BLM. 2005. Nmyc plays an essential role during lung development as a dosage-sensitive regulator of progenitor cell proliferation and differentiation. Development 132: 1363-1374.

Olbrich H, Schmidts M, Werner C, Onoufriadis A, Loges NT, Raidt J, Banki NF, Shoemark A, Burgoyne T, Al Turki S, et al. 2012. Recessive HYDIN mutations cause primary ciliary dyskinesia without randomization of left-right body asymmetry. Am J Hum Genet 91: 672-684.

Oozawa H, Kimura H, Noda T, Hamada K, Morimoto T, Majima Y. 2012. Effect of prehydration on nasal mucociliary clearance in low relative humidity. Auris Nasus Larynx 39: 48-52.

Ostrowski LE. 2002. Ciliogenesis of airway epithelium. In Basic mechanisms of pediatric respiratory disease (ed Haddad GG, Abman SH, Chernick V). BC Decker, Hamilton, ON, Canada.

Ostrowski LE, Blackburn K, Radde KM, Moyer MB, Schlatzer DM, Moseley A, Boucher RC. 2002. A proteomic analysis of human cilia: Identification of novel components. Mol Cell Proteomics 1: 451-465.

Ostrowski LE, Yin W, Rogers TD, Busalacchi KB, Chua M, O’Neal WK, Grubb BR. 2010. Conditional deletion of dnaicl in a murine model of primary ciliary dyskinesia causes chronic rhinosinusitis. Am J Respir Cell Mol Biol 43: 55-63.

O’Toole ET, Giddings TH Jr, Porter ME, Ostrowski LE. 2012. Computer-assisted image analysis of human cilia and Chlamydomonas flagella reveals both similarities and differences in axoneme structure. Cytoskeleton (Hoboken, NJ) 69: 577-590.

Panski B. 1982. Review of medical embryology. Embryome Sciences, Alameda, CA.

Pazour GJ, Agrin N, Walker BL, Witman GB. 2006. Identification of predicted human outer dynein arm genes: Candidates for primary ciliary dyskinesia genes. J Med Genet 43: 62-73.

Pennarun G, Escudier E, Chapelin C, Bridoux AM, Cacheux V, Roger G, Clement A, Goossens M, Amselem S, Duriez B. 1999. Loss-of-function mutations in a human gene related to Chlamydomonas reinhardtii dynein IC78 result in primary ciliary dyskinesia. Am J Hum Genet 65: $1508-$ 1519.

Porter ME, Sale WS. 2000. The $9+2$ axoneme anchors multiple inner arm dyneins and a network of kinases and phosphatases that control motility. J Cell Biol 151: F37-F42.

Raidt J, Wallmeier J, Hjeij R, Onnebrink JG, Pennekamp P, Loges NT, Olbrich H, Häffner K, Dougherty GW, Omran $\mathrm{H}$, et al. 2014. Ciliary beat pattern and frequency in genetic variants of primary ciliary dyskinesia. Eur Respir J 44: 1579-1588.

Ramos FL, Krahnke JS, Kim V. 2014. Clinical issues of mucus accumulation in COPD. Int J Chron Obstruct Pulmon Dis 9: 139-150.

Randell SH, Boucher RC. 2006. Effective mucus clearance is essential for respiratory health. Am J Respir Cell Mol Biol 35: $20-28$.

Rawlins EL, Hogan BLM. 2008. Ciliated epithelial cell lifespan in the mouse trachea and lung. Am J Physiol Lung Cell Mol Physiol 295: L231-L234.

Reid LM, Jones R. 1980. Mucous membrane of respiratory epithelium. Environ Health Perspect 35: 113-120.

Roberts Anthony J, Malkova B, Walker Matt L, Sakakibara H, Numata N, Kon T, Ohkura R, Edwards Thomas A, Knight Peter J, Sutoh K, et al. 2012. ATP-driven remodeling of the linker domain in the dynein motor. Structure 20: $1670-1680$.

Rock JR, Onaitis MW, Rawlins EL, Lu Y, Clark CP, Xue Y, Randell SH, Hogan BLM. 2009. Basal cells as stem cells of the mouse trachea and human airway epithelium. Proc Natl Acad Sci 106: 12771-12775.

Rose MC, Voynow JA. 2005. Respiratory tract mucin genes and mucin glycoproteins in health and disease. Physiol Rev 86: 245-278.

Rose MC, Voynow JA. 2006. Respiratory tract mucin genes and mucin glycoproteins in health and disease. Physiol Rev 86: 245-278.

Rosenbaum JL, Witman GB. 2002. Intraflagellar transport. Nat Rev Mol Cell Biol 3: 813-825. 
Sabater JR, Mao YM, Shaffer C, James MK, O’Riordan TG, Abraham WM. 1999. Aerosolization of $\mathrm{P}_{2} \mathrm{Y}_{2}$-receptor agonists enhances mucociliary clearance in sheep. $J$ Appl Physiol 87: 2191-2196.

Sanderson MJ, Sleigh MA. 1981. Ciliary activity of cultured rabbit tracheal epithelium: Beat pattern and metachrony. J Cell Sci 47: 331-347.

Satir P, Christensen ST. 2007. Overview of structure and function of mammalian cilia. Annu Rev Physiol 69: 377-400.

Satir P, Sleigh MA. 1990. The physiology of cilia and mucociliary interactions. Annu Rev Physiol 52: 137-155.

Schwabe GC, Hoffmann K, Loges NT, Birker D, Rossier C, de Santi MM, Olbrich H, Fliegauf M, Failly M, Liebers U, et al. 2008. Primary ciliary dyskinesia associated with normal axoneme ultrastructure is caused by DNAH11 mutations. Hum Mutat 29: 289-298.

Sears PR, Yin WN, Ostrowski LE. 2015. Continuous mucociliary transport by primary human airway epithelial cells in vitro. Am J Physiol Lung Cell Mol Physiol 309: L99L108.

Shah AS, Ben-Shahar Y, Moninger TO, Kline JN, Welsh MJ. 2009. Motile cilia of human airway epithelia are chemosensory. Science 325: 1131-1134.

Shapiro AJ, Zariwala MA, Ferkol T, Davis SD, Sagel SD, Dell SD, Rosenfeld M, Olivier KN, Milla C, Daniel SJ, et al. 2016. Diagnosis, monitoring, and treatment of primary ciliary dyskinesia: PCD foundation consensus recommendations based on state of the art review. Pediatr Pulmonol 51: 115-132.

Silflow CD, Lefebvre PA. 2001. Assembly and motility of eukaryotic cilia and flagella. Lessons from Chlamydomonas reinhardtii. Plant Physiol 127: 1500-1507.

Simet SM, Sisson JH, Pavlik JA, DeVasure JM, Boyer C, Liu X, Kawasaki S, Sharp JG, Rennard SI, Wyatt TA. 2010. Long-term cigarette smoke exposure in a mouse model of ciliated epithelial cell function. Am J Respir Cell Mol Biol 43: 635-640.

Sleigh MA, Blake JR, Liron N. 1988. The propulsion of mucus by cilia. Am Rev Respir Dis 137: 726-741.

Sorokin SP. 1968. Reconstructions of centriole formation and ciliogenesis in mammalian lungs. J Cell Sci 3: 207230.

Stubbs JL, Vladar EK, Axelrod JD, Kintner C. 2012. Multicilin promotes centriole assembly and ciliogenesis during multiciliate cell differentiation. Nat Cell Biol 14: 140 147.

Sutto Z, Conner GE, Salathe M. 2004. Regulation of human airway ciliary beat frequency by intracellular $\mathrm{pH}$. J Physiol 560: 519-532.

Tarkar A, Loges NT, Slagle CE, Francis R, Dougherty GW, Tamayo JV, Shook B, Cantino M, Schwartz D, Jahnke C, et al. 2013. DYX1C1 is required for axonemal dynein assembly and ciliary motility. Nat Genet 45: 9951003.

Tarran R, Button B, Picher M, Paradiso AM, Ribeiro CM, Lazarowski ER, Zhang L, Collins PL, Pickles RJ, Fredberg JJ, et al. 2005. Normal and cystic fibrosis airway surface liquid homeostasis: The effects of phasic shear stress and viral infections. J Biol Chem 280: 35751-35759.

Tos M. 1966. Development of the tracheal glands in man. Number, density, structure, shape, and distribution of mucous glands elucidated by quantitative studies of whole mounts. Acta Pathol Microbiol Scand 68.

Tsao PN, Chen F, Izvolsky KI, Walker J, Kukuruzinska MA, $\mathrm{Lu}$ J, Cardoso WV. 2008. $\gamma$-Secretase activation of notch signaling regulates the balance of proximal and distal fates in progenitor cells of the developing lung. J Biol Chem 283: 29532-29544.

Vladar EK, Mitchell BJ. 2016. It's a family act: The geminin triplets take center stage in motile ciliogenesis. $E M B O J$ 35: 904-906.

Vladar EK, Lee YL, Stearns T, Axelrod JD. 2015. Observing planar cell polarity in multiciliated mouse airway epithelial cells. Method Cell Biol 127: 37-54.

Walker WT, Young A, Bennett M, Guy M, Carroll M, Fleming J, Conway J, Lucas JS. 2014. Pulmonary radioaerosol mucociliary clearance in primary ciliary dyskinesia. Eur Respir J 44: 533-535.

Wanner A, Salathe M, O’Riordan TG. 1996. Mucociliary clearance in the airways. Am J Respir Crit Care Med 154: $1868-1902$.

Werner ME, Hwang P, Huisman F, Taborek P, Yu CC, Mitchell BJ. 2011. Actin and microtubules drive differential aspects of planar cell polarity in multiciliated cells. $J$ Cell Biol 195: 19-26.

Williams R, Rankin N, Smith T, Galler D, Seakins P. 1996. Relationship between the humidity and temperature of inspired gas and the function of the airway mucosa. Crit Care Med 24: 1920-1929.

Wine JJ, Joo NS. 2004. Submucosal glands and airway defense. Proc Am Thorac Soc 1: 47-53.

Wyatt TA. 2015. Cyclic GMP and cilia motility. Cells 4: 315330.

Yagi T. 2009. Bioinformatic approaches to dynein heavy chain classification. In Methods in cell biology (ed. Stephen MK, Gregory JP), pp. 1-9. Academic, New York.

Yeates DB, Pitt BR, Spektor DM, Karron GA, Albert RE. 1981. Coordination of mucociliary transport in human trachea and intrapulmonary airways. J Appl Physiol 51: 1057-1064.

You Y, Huang T, Richer EJ, Schmidt JEH, Zabner J, Borok Z, Brody SL. 2004. Role of f-box factor foxj1 in differentiation of ciliated airway epithelial cells. Am J Physiol Lung Cell Mol Physiol 286: L650-L657.

Zariwala MA, Knowles MR, Leigh MW. 2007. Primary ciliary dyskinesia. In Gene reviews (ed. Pagon RA, Adam MP, Ardinger HH, Wallace SE, Amemiya A, Bean LJH, Bird TD, Fong CT, Mefford HC, Smith RJH, et al.), pp. 1993-2016. University of Washington, Seattle, WA.

Zhang L, Button B, Gabriel SE, Burkett S, Yan Y, Skiadopoulos MH, Dang YL, Vogel LN, McKay T, Mengos A, et al. 2009. CFTR delivery to $25 \%$ of surface epithelial cells restores normal rates of mucus transport to human cystic fibrosis airway epithelium. PLoS Biol 7: e1000155.

Zhou F, Narasimhan V, Shboul M, Chong Yan L, Reversade B, Roy S. 2015. GMNC is a master regulator of the multiciliated cell differentiation program. Curr Biol 25: $3267-$ 3273.

Zhu Y, Ehre C, Abdullah LH, Sheehan JK, Roy M, Evans CM, Dickey BF, Davis CW. 2008. Munc13-2 ${ }^{-/-}$baseline secretion defect reveals source of oligomeric mucins in mouse airways. J Physiol 586: 1977-1992. 